\title{
Should Quality of Glycemic Control Guide Dental Implant Therapy in Patients with Diabetes? Focus on: Peri-Implant Diseases
}

\author{
Salwa Aldahlawi (1D \\ Dalia Nourah' \\ Sebastiano Andreana ${ }^{2}$ \\ 'Department of Basic and Clinical Oral \\ Sciences, Faculty of Dentistry, Umm Al- \\ Qura University, Makkah, Saudi Arabia; \\ ${ }^{2}$ School of Dental Medicine, University at \\ Buffalo, Buffalo, NY, USA
}

Background and Aim: Traditionally patients with metabolic conditions such as diabetes mellitus are considered not suitable candidates for dental implant therapy due to increased risk of infection, impaired bone healing or the potential for vascular complications. Periimplantitis as the more progressive form of peri-implant disease involves bone loss and estimated to occur in nearly half of all implant cases long-term. Despite extensive research on association of hyperglycemia with dental implants in preclinical and animal models, translational effort to clinical practice is hampered by discrepancies in reported outcome indicators for peri-implantitis in patients with a spectrum of glycemic profiles. This review aims to evaluate clinical evidence for peri-implant disease in metabolically compromised patients and in particular in patients with poorly-controlled diabetes in order to inform clinical management of peri-implant disease.

Materials and Methods: A comprehensive literature review was performed utilizing PubMed database and using the key word 'diabetes' combined with "dental implant" or "Periimplantitis" or/and "Preimplant disease".

Results: Clinical studies with follow up more than 1year, systematic review and metaanalysis that evaluated peri-implant disease in diabetic patients in relation to glycemic control were taken into consideration in this review.

Conclusion: Studies reported conflicting results regarding the long-term effect of diabetes on peri-implant health regardless of the level glycemic control. Therefore, interpretation of finding and relevance to clinical practise should be considered on individual bases.

Keywords: dental implant, diabetes, glycemic control, osseointegration

\section{Introduction}

Peri-implant disease is characterized by plaque-induced inflammation of the oral soft tissue as peri-implant mucositis which can progress to peri-implantitis condition with peri-implant marginal bone loss (MBL) involvement. ${ }^{1}$ Nearly half of all implant cases followed up to 19 years reportedly developed peri-implant mucositis $^{2,3}$ with those without maintenance care progressing to peri-implantitis. ${ }^{4}$ Current treatment approaches for peri-implantitis is especially challenging in metabolically compromised patients such as in diabetes. Hyperglycemia is considered an important risk factor for peri-implant diseases especially peri-implantitis which adversely affects bone metabolism. ${ }^{5}$ Diabetes is a metabolic condition characterized by destruction of hepatic cells in type 1 diabetes and impaired insulin function in type 2 diabetes mellitus (T2DM). Furthermore, microvascular complication of
Correspondence: Salwa Aldahlawi Faculty of Dentistry, Umm Al-Qura University, Taif Road, Al-abdiyyah, Makkah City, Saudi Arabia

Tel +966500559365

Fax +966 I25274203

Email Sadahlaawi@uqu.edu.sa 
T2DM contributes to impaired immune response and bone remodelling leading to delayed healing and potentiating peri-implant infections. ${ }^{6}$

Similar to the heterogeneity of clinical evidence on dental implant survival, the research on association of peri-implant diseases in patients with diabetes in particular those with poorly-controlled glycemic profile is inconsistent and largely scarce with majority of relevant studies only emerging in the last four years. The evidence for the impact of diabetes on survival of dental implant has been discussed in part one of this series. In this second part we aim to focus on the evaluation of clinical evidence for the main complications of implant therapy as peri-implant diseases in patients with diabetes, in particularly poorlycontrolled diabetes.

\section{Diabetes and Peri-Implant Disease Implications of Glycemic Control on Peri-Implant Immune Response}

Altered host response combined with environment inducive to excessive bacterial-plaque accumulation due to hyperglycemia is likely to contribute to more pronounced progression of peri-implant disease in patients with diabetes than metabolically healthy individuals. ${ }^{7,8}$ The underlying molecular mechanisms leading to impaired bone metabolism and poor osseointegration of implants together with the intricate signaling cascade influenced by hyperglycemia have been comprehensively discussed elsewhere. ${ }^{5,9}$ Given that there is lack of predictable therapies for management of peri-implant diseases in general, understanding host response at the bone to dental implant interface could provide important indicators or biomarkers for early diagnosis and design of tailored-therapies in management of metabolically compromised patients. ${ }^{10}$ Furthermore, evidence of inflammatory response modulators may help to identify patients with diabetes at increased risk of developing peri-implant disease. ${ }^{7}$

Several lines of evidence indicate specific cytokine levels (eg IL-1 $\beta$, IL-8 and TNF-a) in peri-implant crevicular fluid of patients with peri-implantitis compared to that of healthy patients markedly influence the host response leading to bone loss. ${ }^{7,11,12}$ In particular, in patients with poor glycemic control, high expression of IL-8 and TNF-a has been detected in peri-implantitis sites compared to well-controlled diabetes patient and healthy individuals. $^{13}$ In addition to the potential inflammatory mediators of peri-implantitis, in patients with peri- implantitis high levels of the matrix metalloproteinase collagenase MMP-8 has been detected in active periimplantitis with progressive bone $\operatorname{loss}^{14}$ and considered an early indicator of peri-implant inflammation. ${ }^{15}$ MMP8 belongs to the family of metal-dependent neutral proteases and has a dual role in immune protection as well as inflammatory pathogenesis. ${ }^{16}$ Similarly, in patients with diabetes significantly elevated salivary MMP-8 concentrations compared to healthy patients and independent of periodontal inflammation has been detected. ${ }^{17}$ However, it is not known whether MMP-8 levels are different between healthy and poorly-controlled diabetes patients with peri-implantitis and more research is needed to determine diagnostic value of MMP- 8 in diabetes. A recent cross-sectional study of diabetic patients with different glycemic profile found abnormal levels of bone metabolism biomarkers vitamin D and osteocalcin in T2DM patients with poorly-controlled glycemic profile and concluded that hyperglycemia was an independent risk factor for these biomarkers. ${ }^{18}$

The hallmark of peri-implantitis is collagenase matrix degradation accompanied by alveolar bone $\operatorname{loss}^{19}$ and overproduction of advanced glycation end products (AGEs) which further contributes to the destruction of periodontal tissue. ${ }^{20}$ Despite differences in histopathological presentation, the underlying mechanism of pathogenesis of peri-implant diseases is very similar to periodontal disease $^{21}$ involving chronic inflammatory and immune responses to bacterial biofilm although the size of the inflammatory connective tissue at the implant site is reportedly twice as large as the tooth sites indicating a potentially more aggressive progression clinical profile. ${ }^{19}$ Similar to chronic periodontitis, the main clinical markers of peri-implantitis in addition to soft tissue inflammation and suppuration include bleeding on probing (BOP), plaque index (PI) and probing depth (PD) while marginal bone level is a radiographic marker. ${ }^{22}$ However, clinical studies do not consistently report on all of these outcome indicators when comparing patients with diabetes to non-diabetes making comparisons across studies challenging. ${ }^{23}$

There is clinical evidence in diabetic patients for increased levels of advanced glycation end products (AGEs) in their peri-implant sulcular fluid ${ }^{24}$ especially in patients with poorly-controlled glycemic profile $(>10 \%$ HbAlc levels). ${ }^{25}$ Since AGEs are involved in negative modulation of bone metabolism and remodeling, therefore higher levels of AGEs especially in diabetic patients with 
poor glycemic profile could serve as a potentially promising biomarker for peri-implantitis. ${ }^{25}$

Recent experimental studies have shown improved osteoblast adhesion and differentiation due to modulation of oxidative stress by the released titanium from dental implant. ${ }^{26}$ In diabetes, however, the evidence from preclinical and animal studies suggest that at the bone to dental implant interface, hyperglycemia results in reduced bone formation due to impaired angiogenesis which is proposed to have resulted from excessive oxidate stress production affecting several key signaling pathways. ${ }^{5,27}$ Furthermore, diabetes-induced oxidative stress results in impaired osteoblast function on titanium surfaces through inactivation of the canonical Wnt signaling pathway $(\mathrm{Wnt} / \beta \text {-catenin })^{28}$ which is involved in bone healing through differentiation and matrix production of osteoblasts. ${ }^{29}$ Further investigations of the underlying biological mechanisms adversely affected by hyperglycemia at the bone to dental implant interface and understanding the potential impact of periimplant disease in metabolically compromised patients will facilitate the design of novel targeted therapies to manage peri-implantitis in this vulnerable group.

\section{Clinical Evidence for Association of Hyperglycemia with Peri-Implant Disease}

Although emerging evidence from a number of systematic reviews and meta-analyses suggest that chronic hyperglycemia is an important risk factor for peri-implant diseases, ${ }^{23,30,31}$ however more recent lines of evidence do not indicate any significant association between diabetes and peri-implantitis. ${ }^{6,32,33}$ Several recent metaanalyses have shown that diabetes and in particular poor glycemic control significantly correlates with predisposition and development of peri-implantitis. ${ }^{23,30,31} \mathrm{~A}$ recent meta-analysis found that compared to non-diabetics, twice as many patients with diabetes were at risk of periimplantitis and that higher glycemic levels (HbA1c $>8 \%$ ) were associated with greater prevalence of peri-implant diseases. ${ }^{30}$ Similarly, another meta-analysis found that patients with diabetes were at a significantly higher risk of peri-implantitis than healthy controls. ${ }^{31}$ However, other more recent studies have not found a similar trend between diabetes and peri-implantitis compared to metabolically healthy individuals. ${ }^{6,32,33}$ While two studies only looked at patients with well-controlled diabetes, ${ }^{6,32,33}$ in another independent study the male patients with poorly-controlled diabetes $(\mathrm{HbA} 1 \mathrm{c}>8 \%)$ showed elevated peri-implant clinical and radiographic markers independent of periimplantitis. ${ }^{6}$ Collectively, these studies emphasize the need for further well-controlled and long-term trials that compare patients with different glycemic profiles using consistent definitions as well as outcome indicators which can then be translated to appropriate management during implant therapy. Table 1 summarize the evidence from systematic reviews and meta-analyses on link between diabetes and peri-implant diseases.

\section{Diabetes Comorbidities and Peri-Implant Diseases}

While the impact of diabetes on implant therapy has been extensively researched, much less is known of the role of other associated comorbidities such as obesity where studies have been focusing on adipose-derived inflammation as the cause for deterioration of oral health in this population. ${ }^{34}$ Obesity has been shown to be associated with severity of periodontal disease $\mathrm{e}^{35-37}$ and therefore likely a contributing factor to the progression of periodontal disease in peri-implantitis. ${ }^{38}$

In obese patients with increasing body mass index high serum C-reactive protein (an inflammatory biomarker) was significantly associated with peri-implant bleeding. ${ }^{39}$ Another study showed that compared to control group in patients with obesity both PD and MBL were significantly increased after 5 years of follow-up. ${ }^{40}$ Furthermore, individuals with obesity have a markedly higher levels of proinflammatory biomarkers in peri-implant crevicular fluid compared to non-obese individuals. ${ }^{41}$ A meta-analysis of six studies showed a significant association between obesity and decreased peri-implant health outcomes although the authors did not rule out the potential effects of different length and type of implants on peri-implant markers as confounding factors reported in identified studies. ${ }^{42}$

Despite limited studies on patients with diabetes and obesity, nevertheless available clinical evidence supports the association of obesity with the development of periimplantitis. ${ }^{5,39-41}$ In a recent study, patients with diabetes (HbAlc $>8.1$ ) and high BMI showed significantly higher PI, BOP, PD and bone loss compared to the non-diabetic patients after a mean of 6.3 years follow-up. In addition, this study showed that patients with diabetes had markedly higher AGEs in their crevicular fluid. ${ }^{25}$ Although a recent meta-analyses of 12 studies on the effect of hyperglycemia and peri-implantitis reported a higher risk in diabetes versus non-diabetes study 
Table I Summary of Evidence from Systematic Reviews and Meta-Analyses on Link Between Diabetes and Peri-Implant Diseases

\begin{tabular}{|c|c|c|c|c|c|c|}
\hline $\begin{array}{l}\text { Study } \\
\text { (Year) }\end{array}$ & $\begin{array}{l}\text { Study } \\
\text { Design }\end{array}$ & Focus of Study & $\begin{array}{l}\text { Studies } \\
\text { Identified }\end{array}$ & $\begin{array}{l}\text { Follow- } \\
\text { Up } \\
\text { (Years) }\end{array}$ & DI Findings & Conclusions \\
\hline $\begin{array}{l}\text { Jiang et al } \\
(2020)^{23}\end{array}$ & Meta & $\begin{array}{l}\text { Osteointegration } \\
\text { based on } \\
\text { biological } \\
\text { parameter } \\
\text { measures* }\end{array}$ & $\begin{array}{l}10 \text { clinical } \\
\text { studies }\end{array}$ & $\begin{array}{l}1-7 \\
\text { Years }\end{array}$ & $\begin{array}{l}\text { Significant marginal bone loss only in } 3 \\
\text { studies. Increased bleeding in four } \\
\text { studies }(p<0.00001)\end{array}$ & $\begin{array}{c}\text { Bleeding around DI was } \\
\text { significant irrespective of } \\
\text { HbA Ic levels in patients with } \\
\text { diabetes }\end{array}$ \\
\hline $\begin{array}{l}\text { Lagunov et al } \\
(2019)^{46}\end{array}$ & Meta & $\begin{array}{l}\text { Osteointegration } \\
\text { based on } \\
\text { biological } \\
\text { parameter } \\
\text { measures* }\end{array}$ & $\begin{array}{l}7 \text { clinical } \\
\text { studies }\end{array}$ & $\begin{array}{l}1-12 \\
\text { Years }\end{array}$ & $\begin{array}{c}\text { Significant marginal bone loss } \\
(p<0.00 \mathrm{I}) \text {, bleeding on probing } \\
(\mathrm{p}<0.04) \text { and probing depth }(\mathrm{p}<0.00 \mathrm{I}) \\
\text { in well-controlled T2DM ( } \mathrm{HbAlc} \\
6-8 \%)\end{array}$ & $\begin{array}{c}\text { Despite no significant } \\
\text { difference in DI survival, } \\
\text { patients with T2DM were at } \\
\text { higher risk of peri-implantitis }\end{array}$ \\
\hline $\begin{array}{l}\text { Meza } \\
\text { Maurício et al } \\
(2019)^{47}\end{array}$ & UR & $\begin{array}{l}\text { Peri-implant } \\
\text { diseases }\end{array}$ & $\begin{array}{l}2 \text { SR \& I } \\
\text { Meta** }\end{array}$ & $\begin{array}{c}2 \\
\text { months- } \\
\text { 2I Years }\end{array}$ & $\begin{array}{l}\text { Only } 3 \text { reviews provided evidence } \\
\text { from limited number of studies }\end{array}$ & $\begin{array}{l}\text { Insufficient evidence to } \\
\text { support diabetes associated } \\
\text { with peri-implant diseases }\end{array}$ \\
\hline $\begin{array}{l}\text { Papi et al } \\
(2018)^{48}\end{array}$ & $S R$ & $\begin{array}{c}\text { Peri-implant } \\
\text { disease and MetS }\end{array}$ & $\begin{array}{l}5 \text { clinical } \\
\text { studies } \\
\text { and I SR }\end{array}$ & $\begin{array}{l}\text { Not } \\
\text { reported }\end{array}$ & $\begin{array}{l}\text { Only reported findings of Monje et al } \\
\qquad(2017)\end{array}$ & $\begin{array}{l}\text { There is lack of reported } \\
\text { research on association of } \\
\text { peri-implant disease and } \\
\text { hyperglycemia component of } \\
\text { MetS }\end{array}$ \\
\hline $\begin{array}{l}\text { Monje et al } \\
(2017)^{30}\end{array}$ & Meta & $\begin{array}{l}\text { Peri-implant } \\
\text { diseases }\end{array}$ & $\begin{array}{l}7 \text { clinical } \\
\text { studies }\end{array}$ & $\begin{array}{l}1-16 \\
\text { Years }\end{array}$ & $\begin{array}{l}50 \% \text { higher risk of peri-implantitis in } \\
\text { non-smoker patients with diabetes } \\
\text { than in healthy controls }\end{array}$ & $\begin{array}{c}\text { Patients with diabetes at } \\
\text { higher risk of peri-implantitis }\end{array}$ \\
\hline $\begin{array}{l}\text { Tseng } \\
\text { et al }(2016)^{31}\end{array}$ & Meta & $\begin{array}{l}\text { Peri-implant } \\
\text { diseases }\end{array}$ & $\begin{array}{l}5 \text { clinical } \\
\text { studies }\end{array}$ & $\begin{array}{l}\text { Not } \\
\text { reported }\end{array}$ & $\begin{array}{l}\text { Significant relationship between peri- } \\
\text { implantitis and diabetes (OR, I.89; } \\
\quad 95 \% \mathrm{Cl}, \mathrm{I} .3 \mathrm{I}-2.46)\end{array}$ & $\begin{array}{l}\text { Limited number of studies. } \\
\text { Caution should be observed } \\
\text { when implants are placed in } \\
\text { patients with diabetes }\end{array}$ \\
\hline
\end{tabular}

Notes: *Osseointegration biological parameters measured: marginal bone loss, probing depth and bleeding on probing. ** Only two SR and one Meta were related to periimplant diseases.

Abbreviations: DI, dental implant; Meta, meta-analysis; MetS, metabolic syndrome; SR, systematic review; HbAIc, glycosylated hemoglobin AIc; T2DM, type 2 diabetes mellitus; AGEs, advanced glycation end products; BMI, body mass index; BOP, bleeding on probing; PI, plaque index; PD, probing depth; Wnt/ $\beta$-catenin, Wnt signaling pathway.

subjects, however most of the included studies did not address the effects of confounding factors such as history of periodontal disease or poor plaque control ${ }^{30}$ despite strong evidence suggesting these factors are significant risk factors for periimplantitis. $^{43,44}$ Majority of eligible studies in the metaanalysis did not report any oral hygiene measures (89\%) with only $11 \%$ of the studies reporting that study subjects had good oral hygiene. A more recent study of short dental implants showed that in patients with poorly-controlled T2DM (HbA1c 7.3 to $10.5 \%)$ and high BMI $\left(37 \mathrm{~kg} / \mathrm{m}^{2}\right)$, the variables of PI (P $<0.01)$, BOP $(\mathrm{P}<00.01)$ and radiographic bone loss $(\mathrm{P}<0.01)$ and therefore risk of peri-implantitis increased significantly compared to healthy patients. However, the increase in bone loss for the diabetic group remained statistically significant after adjusting for $\mathrm{HbA1c}$, lipids as well as $\mathrm{BMI}(\mathrm{P}<0.05)$ indicating other pathways than inflammation may be involved which needs further clarification. ${ }^{45}$ Moreover, although there is currently very limited evidence on the impact of smoking and peri-implant disease in diabetes patients, preliminary data suggests that smoking does not exacerbate peri-implantitis in diabetes. $^{30}$

\section{Conclusion}

The literature linking glycaemic control to peri-implant disease is highly heterogeneous due to lack of consistency of the definition of peri-implantitis and its clinical 
indicators among studies. Consensus on the criteria for diagnosis of peri-implant diseases requires standardization of clinical and radiological outcome indicators in research. In addition, other factors that affects peri implant health like high BMI, history of periodontal disease, oral hygiene and smoking is unequivocal but not well-researched especially in diabetic patients. Research on bone biomarkers will also provide additional diagnostic tool for early diagnosis and management of active peri-implant diseases. Together with monitoring glycemic profile of patients with diabetes, oral implant rehabilitation and associated complications in this metabolically compromised population will be more predictable.

\section{Disclosure}

The authors report no conflicts of interest in this work.

\section{References}

1. Rosen P, Clem D, Cochran D, et al. Peri-implant mucositis and peri-implantitis: a current understanding of their diagnoses and clinical implications. J Periodontol. 2013;84(4):436-443.

2. Derks J, Tomasi C. Peri-implant health and disease. A systematic review of current epidemiology. J Clin Periodontol. 2015;42:S158S171. doi:10.1111/jepe.12334

3. Krebs M, Kesar N, Begić A, von Krockow N, Nentwig GH, Weigl P. Incidence and prevalence of peri-implantitis and peri-implant mucositis 17 to 23 (18.9) years postimplant placement. Clin Implant Dent Relat Res. 2019;21(6):1116-1123. doi:10.1111/cid.12848

4. Costa FO, Takenaka-Martinez S, Cota LOM, Ferreira SD, Silva GLM, Costa JE. Peri-implant disease in subjects with and without preventive maintenance: a 5-year follow-up. $J$ Clin Periodontol. 2012;39(2):173-181. doi:10.1111/j.1600051X.2011.01819.x

5. de Oliveira PGFP, Bonfante EA, Bergamo ET, et al. Obesity/metabolic syndrome and diabetes mellitus on peri-implantitis. Trends Endocrinol Metabol. 2020;31:596-610. doi:10.1016/j. tem.2020.05.005

6. Al-Askar M, Ajlan S, Alomar N, Al-Daghri NM. Clinical and radiographic peri-implant parameters and whole salivary interleukin- $1 \beta$ and interleukin-6 levels among type- 2 diabetic and nondiabetic patients with and without peri-implantitis. Med Principles Pract. 2018;27(2):133-138. doi:10.1159/000488032

7. Corrêa MG, Pimentel SP, Ribeiro FV, Cirano FR, Casati MZ. Host response and peri-implantitis. Braz Oral Res. 2019;33. doi:10.1590/ 1807-3107bor-2019.vol33.0066

8. Cervino G, Terranova A, Briguglio F, et al. Diabetes: oral health related quality of life and oral alterations. Biomed Res Int 2019;2019:5907195. doi:10.1155/2019/5907195

9. Murray CE, Coleman CM. Impact of diabetes mellitus on bone health. Int J Mol Sci. 2019;20(19):4873. doi:10.3390/ijms20194873

10. Matarese G, Ramaglia L, Fiorillo L, Cervino G, Lauritano F, Isola G. Implantology and periodontal disease: the panacea to problem solving? Open Dent J. 2017;11:460-465. doi:10.2174/ 1874210601711010460

11. Alassy H, Parachuru P, Wolff L. Peri-implantitis diagnosis and prognosis using biomarkers in peri-implant crevicular fluid: a narrative review. Diagnostics (Basel). 2019;9(4):214. doi:10.3390/ diagnostics 9040214
12. Ting M, Craig J, Balkin BE, Suzuki JB. Peri-implantitis: a comprehensive overview of systematic reviews. $J$ Oral Implantol. 2018;44(3):225-247. doi:10.1563/aaid-joi-D-16-00122

13. Venza I, Visalli M, Cucinotta M, De Grazia G, Teti D, Venza M. Proinflammatory gene expression at chronic periodontitis and periimplantitis sites in patients with or without type 2 diabetes. J Periodontol. 2010;81(1):99-108. doi:10.1902/jop.2009.090358

14. Arakawa H, Uehara J, Hara ES, et al. Matrix metalloproteinase-8 is the major potential collagenase in active peri-implantitis. $J \quad$ Prosthodont Res. 2012;56(4):249-255. doi:10.1016/j. jpor.2012.07.002

15. Basegmez C, Yalcin S, Yalcin F, Ersanli S, Mijiritsky E. Evaluation of periimplant crevicular fluid prostaglandin E2 and matrix metalloproteinase- 8 levels from health to periimplant disease status: a prospective study. Implant Dent. 2012;21(4):306-310. doi:10.1097/ ID.0b013e3182588408

16. Le N, Xue M, Castelnoble LA, Jackson CJ. The dual personalities of matrix metalloproteinases in inflammation. Front Biosci. 2007;12 (1):475. doi: $10.2741 / 2161$

17. Costa PP, Trevisan GL, Macedo GO, et al. Salivary interleukin-6, matrix metalloproteinase- 8 , and osteoprotegerin in patients with periodontitis and diabetes. $J$ Periodontol. 2010;81(3):384-391. doi:10.1902/jop.2009.090510

18. Zhao H, Qi C, Zheng C, Gan K, Ren L, Song G. Effects of glycated hemoglobin level on bone metabolism biomarkers in patients with type 2 diabetes mellitus. Diabetes Metab Syndr Obes. 2020;13:1785-1791. doi:10.2147/DMSO.S248844

19. Carcuac O, Berglundh T. Composition of human peri-implantitis and periodontitis lesions. $J$ Dent Res. 2014;93(11):1083-1088. doi:10.1177/0022034514551754

20. Al Zahrani S, Al Mutairi AA. Crestal bone loss around submerged and non-submerged dental implants in individuals with type-2 diabetes mellitus: a 7-year prospective clinical study. Med Principles Pract. 2019;28(1):75-81. doi:10.1159/000495111

21. Salvi GE, Cosgarea R, Sculean A. Prevalence and mechanisms of peri-implant diseases. J Dent Res. 2017;96(1):31-37. doi:10.1177/ 0022034516667484

22. Finne K, Rompen E, Toljanic J. Prospective multicenter study of marginal bone level and soft tissue health of a one-piece implant after two years. J Prosthet Dent. 2007;97(6):S79-S85. doi:10.1016/ S0022-3913(07)60011-0

23. Jiang X, Zhu Y, Liu Z, Tian Z, Zhu S. Association between diabetes and dental implant complications: a systematic review and meta-analysis. Acta Odontol Scand. 2020;1-10.

24. Alrabiah M, Al-Aali KA, Al-Sowygh ZH, Binmahfooz AM, Mokeem SA, Abduljabbar T. Association of advanced glycation end products with peri-implant inflammation in prediabetes and type 2 diabetes mellitus patients. Clin Implant Dent Relat Res. 2018;20(4):535-540. doi:10.1111/cid.12607

25. Al-Sowygh ZH, Ghani SMA, Sergis K, Vohra F, Akram Z. Periimplant conditions and levels of advanced glycation end products among patients with different glycemic control. Clin Implant Dent Relat Res. 2018;20(3):345-351. doi:10.1111/cid.12584

26. Rossi M, Bezerra F, Silva R, et al. Titanium-released from dental implant enhances pre-osteoblast adhesion by ROS modulating crucial intracellular pathways. $J$ Biomed Mater Res A. 2017;105 (11):2968-2976. doi:10.1002/jbm.a.36150

27. Hu X-F, Wang L, Xiang G, Lei W, Feng Y-F. Angiogenesis impairment by the NADPH oxidase-triggered oxidative stress at the bone-implant interface: critical mechanisms and therapeutic targets for implant failure under hyperglycemic conditions in diabetes. Acta Biomaterialia. 2018;73:470-487. doi:10.1016/j.actbio.2018.04.008

28. Ma X-Y, Feng Y-F, Ma Z-S, et al. The promotion of osteointegration under diabetic conditions using chitosan/hydroxyapatite composite coating on porous titanium surfaces. Biomaterials. 2014;35 (26):7259-7270. doi:10.1016/j.biomaterials.2014.05.028 
29. Wang T, Zhang X, Bikle DD. Osteogenic differentiation of periosteal cells during fracture healing. J Cell Physiol. 2017;232(5):913-921. doi:10.1002/jcp.25641

30. Monje A, Catena A, Borgnakke WS. Association between diabetes mellitus/hyperglycaemia and peri-implant diseases: systematic review and meta-analysis. J Clin Periodontol. 2017;44(6):636-648. doi: $10.1111 /$ jcpe. 12724

31. Tseng K-C, Zheng X-Y, Qu X-H, Lu E-Y. Risk of peri-implantitis in patients with diabetes mellitus: a meta-analysis. Int J Clin Exp Med. 2016;9(8):15986-15995.

32. Alberti A, Morandi P, Zotti B, et al. Influence of diabetes on implant failure and peri-implant diseases: a retrospective study. Dent J. 2020;8(3):70. doi:10.3390/dj8030070

33. Sghaireen MG, Alduraywish AA, Srivastava KC, et al. Comparative evaluation of dental implant failure among healthy and well-controlled diabetic patients-a 3-year retrospective study. Int J Environ Res Public Health. 2020;17(14):5253. doi:10.3390/ ijerph17145253

34. Di Benedetto A, Gigante I, Colucci S, Grano M. Periodontal disease: linking the primary inflammation to bone loss. Clin Dev Immunol. 2013;2013:1-7. doi:10.1155/2013/503754

35. Gul SS, Imran NK, Al-Sharqi AJB, Abdulkareem AA. Association of overweight/obesity with the severity of periodontitis using BPE code in an iraqi population. Clin Epidemiol Global Health. 2020.

36. Martinez-Herrera M, Silvestre-Rangil J, Silvestre FJ. Association between obesity and periodontal disease. A systematic review of epidemiological studies and controlled clinical trials. Med Oral Patol Oral Cir Bucal. 2017;22(6):e708-e715. doi:10.4317/ medoral.21786

37. Palle AR, Reddy CSK, Shankar BS, Gelli V, Sudhakar J, Reddy KKM. Association between obesity and chronic periodontitis: a cross-sectional study. J Contemp Dent Pract. 2013;14(2):168. doi:10.5005/jp-journals-10024-1294

38. Isola G, Polizzi A, Patini R, Ferlito S, Alibrandi A, Palazzo G. Association among serum and salivary A. actinomycetemcomitans specific immunoglobulin antibodies and periodontitis. BMC Oral Health. 2020;20(1):283. doi:10.1186/s12903-020-01258-5

39. Vohra F, Alkhudhairy F, Al-Kheraif AA, Akram Z, Javed F. Periimplant parameters and C-reactive protein levels among patients with different obesity levels. Clin Implant Dent Relat Res. 2018;20 (2):130-136. doi:10.1111/cid.12556
40. Alkhudhairy F, Vohra F, Al-Kheraif AA, Akram Z. Comparison of clinical and radiographic peri-implant parameters among obese and non-obese patients: a 5-year study. Clin Implant Dent Relat Res. 2018;20(5):756-762. doi:10.1111/cid.12633

41. Alasqah MN, Al-Shibani N, Al-Aali KA, Qutub OA, Abduljabbar T, Akram Z. Clinical indices and local levels of inflammatory biomarkers in per-implant health of obese and nonobese individuals. Clin Implant Dent Relat Res. 2019;21(1):80-84. doi:10.1111/cid.12700

42. Monteiro JLGC, Pellizzer EP, Araújo Lemos CA, de Moraes SLD, Do Egito Vasconcelos BC. Is there an association between overweight/obesity and dental implant complications? A systematic review and meta-analysis. Int J Oral Maxillofac Surg. 2019;48 (9):1241-1249. doi:10.1016/j.ijom.2019.01.015

43. Rösing CK, Fiorini T, Haas AN, Muniz FWMG, Oppermann RV, Susin C. The impact of maintenance on peri-implant health. Braz Oral Res. 2019;33. doi:10.1590/1807-3107bor-2019.vol33.0074

44. Stacchi C, Berton F, Perinetti G, et al. Risk factors for peri-implantitis: effect of history of periodontal disease and smoking habits. A systematic review and meta-analysis. J Oral Maxillofacial Res. 2016;7(3). doi:10.5037/jomr.2016.7303.

45. Mokeem S, Alfadda SA, Al-Shibani N, et al. Clinical and radiographic peri-implant variables around short dental implants in type 2 diabetic, prediabetic, and non-diabetic patients. Clin Implant Dent Relat Res. 2019;21(1):60-65. doi:10.1111/cid.12691

46. Lagunov VL, Sun J, George R. Evaluation of biologic implant success parameters in type 2 diabetic glycemic control patients versus health patients: a meta-analysis. J Investig Clin Dent. 2019;10(4): e12478. doi:10.1111/jicd.12478

47. Meza Maurício J, Miranda TS, Almeida ML, Silva HD, Figueiredo LC, Duarte PM. An umbrella review on the effects of diabetes on implant failure and peri-implant diseases. Braz Oral Res. 2019;33. doi:10.1590/1807-3107bor-2019.vol33.0070

48. Papi P, Letizia C, Pilloni A, et al. Peri-implant diseases and metabolic syndrome components: a systematic review. Eur Rev Med Pharmacol Sci. 2018;22:866-875. doi:10.26355/eurrev_201802_14364
Clinical, Cosmetic and Investigational Dentistry

\section{Publish your work in this journal}

Clinical, Cosmetic and Investigational Dentistry is an international, peer-reviewed, open access, online journal focusing on the latest clinical and experimental research in dentistry with specific emphasis on cosmetic interventions. Innovative developments in dental materials, techniques and devices that improve outcomes and patient

\section{Dovepress}

satisfaction and preference will be highlighted. The manuscrip management system is completely online and includes a very quick and fair peer-review system, which is all easy to use. Visit http://www.dovepress.com/testimonials.php to read real quotes from published authors. 